\section{Size and age: intrinsic confounding factors affecting the responses to a water deficit in black spruce seedlings}

\author{
Denis Walsh, Sergio Rossi, Daniel Lord
}

The resistance to stress of seedlings during the initial phases after planting is fundamental for assuring fast establishment and long-term survival of artificial regeneration. Although needing less storage space and handling during their production and planting, small seedlings are considered to be less efficient in terms of water uptake and more sensitive to a water deficit than bigger seedlings. The responses to a water deficit produced by a suspension of irrigation for 14 days were assessed in black spruce (Picea mariana [Mill.] BSP) seedlings of different sizes, with height ranging between 13 and $71 \mathrm{~cm}$. Seedlings growing in containers with cavity volumes of $25,50,110,350 \mathrm{~cm}^{3}$ were tested. During the treatment, the seedlings attained $\boldsymbol{\psi}_{\mathrm{pd}}$ of between -1.71 and $-2.28 \mathrm{MPa}$, indicating that a severe water stress was reached. Smaller seedlings exhibited similar or higher water potential and gas exchanges than bigger seedlings both during and after the treatment. Although root biomass was higher in bigger seedlings, the growth rates of roots were similar between seedling sizes and were not affected by the water stress. The initial hypothesis that small seedlings are more sensitive to water stress was rejected. The delayed stomatal closure and higher $\mathrm{CO}_{2}$ assimilation rate of smaller seedlings during the treatment could be attributed to a lower shoot:root ratio and greater ability of roots to sustain the evaporative needs of needles, which could attain higher performances in carbon assimilation. The potential effects of confounding factors such as age and pre-treatment preventing to identify the main factor affecting drought tolerance in black spruce seedlings were discussed.

Keywords: Artificial Regeneration, Boreal Forest, Containerized Plants, Planting, Water Stress

\section{Introduction \\ Quick and successful post-cutting regene- ration ensures a continuous and sustained productivity of the stands as well as the eco- logical functions and ecosystem services of the forest to be maintained over time. Forest management activities thus have to guaran- tee an appropriate regeneration of harvested stands. In Canada, between 60 and $70 \%$ of the harvested area (mainly conifer stands) is regenerated by artificial means, mainly by planting and seeding to efficiently achieve the desired density and species composition of the future stands (Natural Resources Ca- nada 2012). The huge surface involved has}

extended the planting period during summer in all boreal regions (Tan et al. 2008, Nilsson et al. 2010). In these ecosystems, seedlings planted in late spring benefit from the fresh moist soil conditions due to still low temperatures and abundant water released with snowmelt (Luoranen et al. 2007, Rossi et al. 2011). However, in summer soils lose water at a higher rate than that supplied by precipitation, and soil water content has been observed to decrease down to $20 \%$ during the driest and hottest summer days even at the higher latitudes (Belien et al. 2012). The seedlings newly outplanted under these unfavorable conditions are potentially ex-

$\square$ Département des Sciences Fondamentales, Université du Québec à Chicoutimi, 555 Boulevard de l'Université, Chicoutimi (QC), G7H2B1 (Canada)

@ Sergio Rossi (sergio.rossi@uqac.ca)

Received: Jul 30, 2014 - Accepted: Oct 17, 2014

Citation: Walsh D, Rossi S, Lord D, 2014. Size and age: intrinsic confounding factors affecting the responses to a water deficit in black spruce seedlings. iForest 8: 401-409 [online 2014-12-09] URL: http://www.sisef.it/iforest/contents/?id=ifor1412-007

Communicated by: Giustino Tonon posed to water stress and non-optimal temperatures (Tan 2007).

Artificial regeneration is a useful but expensive component of forest management, with $80 \%$ of the plantation costs being directly related to the seedlings (Johansson et al. 2007). However, seedling survival and growth rates under transient or persistent unfavorable environmental conditions can substantially affect the success and price of the procedure. There can also be important logistic and economic constraints, mainly when the artificial regeneration has to be established in remote stands far from the seedling production areas. In the last decade, there has been increasing interest in the use of smaller and younger seedlings (Lindström et al. 2005, Hébert et al. 2014). Such a strategy has evident financial advantages during the production and planting process. In the nursery, smaller seedlings require less storage space and handling, and a shorter period of growth; in the field, transport and planting times and costs are reduced. In coniferous reforestation areas of Sweden, smaller seedlings have shown higher survival rates than bigger ones because of less pine weevil ( $H y$ lobius abietis L.) damage (Lindström et al. 2005, Danielsson et al. 2008). Competition with the vegetation for light and soil resources can be an important constraint for small seedlings, which show reduced shoot growth during the initial phases after planting (Grossnickle 2000, Johansson et al. 2007). However, the competitive disadvantage of small seedlings has only minimal effects at higher latitudes, where the vegetation is mainly composed of ericaceous shrubs and lichen mat (Hébert et al. 2014). Small seedlings could require special precautions during the preparation and planting in the field, as they are expected to dry out faster than seedlings of conventional sizes because of their smaller root system (Lindström et al. 2005, Johansson et al. 2007). Thus, the water availability in the site represents a crucial factor for the success of the regeneration.

Reduced growth is generally observed in seedlings of boreal species during the 2-3 years following planting. Seedlings have roots enclosed in a small rootball that reduce or inhibit the ability of plants to respond to the water requirements for evapotranspiration (Grossnickle \& Folk 1993). Seedlings of bigger sizes may be considered better adapted to avoid water stress and complete the establishment phase more rapidly due to their higher root biomass and growth, and consequently an increased root-soil contact. Moreover, in respect to small seedlings, the soil volume in the rootball of bigger seedlings may represent a richer reservoir of water available for the plants (Burdett 1990, Jutras et al. 2007) Accordingly, even if economically advantageous, seedlings of small 
Tab. 1 - Characteristics of the seedlings (mean \pm standard deviation, $\mathrm{n}=20$ ) and their growing containers (C25, C50, C110, C350 - see also Fig. 1). (DW): dry weight.

\begin{tabular}{|c|c|c|c|c|c|}
\hline Item & Characteristics & $\mathrm{C25}$ & $\mathbf{C 5 0}$ & C110 & C350 \\
\hline \multirow{3}{*}{ 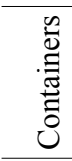 } & Number of cavities & 113 & 67 & 45 & 25 \\
\hline & Cavity depth $(\mathrm{cm})$ & 7.5 & 8 & 12 & 12.5 \\
\hline & Cavity volume $\left(\mathrm{cm}^{3}\right)$ & 25 & 50 & 110 & 350 \\
\hline \multirow{9}{*}{ 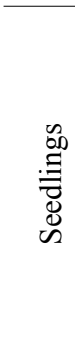 } & Seedling age (yrs) & 2 & 2 & 3 & 3 \\
\hline & Seedling height $(\mathrm{cm})$ & $12.82 \pm 1.04$ & $20.28 \pm 2.53$ & $31.81 \pm 3.77$ & $71.32 \pm 4.38$ \\
\hline & Diameter at collar (mm) & $1.9 \pm 0.16$ & $2.54 \pm 0.20$ & $3.71 \pm 0.71$ & $8.18 \pm 0.68$ \\
\hline & $\begin{array}{l}\text { height:diameter ratio } \\
(\mathrm{cm} / \mathrm{mm})\end{array}$ & $6.80 \pm 0.85$ & $8.01 \pm 1.10$ & $8.80 \pm 1.57$ & $8.76 \pm 0.84$ \\
\hline & Needles (DW g) & $0.23 \pm 0.05$ & $0.53 \pm 0.11$ & $1.27 \pm 0.34$ & $7.02 \pm 1.70$ \\
\hline & Stem (DW g) & $0.19 \pm 0.05$ & $0.39 \pm 0.09$ & $0.95 \pm 0.28$ & $9.40 \pm 1.59$ \\
\hline & Roots (DW g) & $0.22 \pm 0.06$ & $0.49 \pm 0.12$ & $0.93 \pm 0.35$ & $6.67 \pm 1.89$ \\
\hline & Shoot:root ratio & $1.90 \pm 0.31$ & $1.91 \pm 0.35$ & $2.56 \pm 0.63$ & $2.61 \pm 0.70$ \\
\hline & Root density $\left(\mathrm{cm}^{3} \mathrm{~cm}^{-3}\right)$ & $2.56 \pm 1.40$ & $6.60 \pm 2.45$ & $4.24 \pm 1.00$ & $7.00 \pm 3.63$ \\
\hline
\end{tabular}

sizes could be less efficient in terms of water and nutrient uptake, which would make them unsuitable in stands with soils that may have low moisture content during the growing season.

The aim of this paper was to assess the response to a severe water deficit of seedlings of different sizes growing under controlled conditions simulating extreme post-planting conditions. The hypothesis that the small size makes seedlings more sensitive to water stress was tested. Such relationships have been in part analyzed previously, but comparisons were made only for seedlings of big sizes and, to our knowledge, no study is available on the responses to water stress of small seedlings (i.e., those produced in cavities with volume of less than $50 \mathrm{~cm}^{3}$ - Lamhamedi et al. 1998, Jobidon et al. 1998). In this study, black spruce (Picea mariana (Mill.) BSP) was used as study species because of its transcontinental distribution and utilization in the boreal forest of northern North-America and its well-known responses to water stress (Hébert et al. 2006, Huang et al. 2010, Nishimura \& Laroque 2011).

\section{Material and Methods}

\section{Experimental design}

The investigation was conducted on 2- and
3 -year-old black spruce seedlings of different sizes and named C25, C50, C110 and C350, according to the cavity volume of the containers in which they were grown (Tab. 1). The containers for $\mathrm{C} 50, \mathrm{C} 110$ and $\mathrm{C} 350$ represented the sizes most used for boreal species. Diameter, height and biomass of seedlings increased while root density decreased with the cavity volume of the container. The container for C25 was specifically designed in 2006 at the Université du Québec à Chicoutimi (Canada) and was characterized by small cavities arranged in a honeycomb pattern (Fig. 1). All containers were produced by IPL Inc. (Saint Damien, Quebec, Canada). Before the experiment, the seedlings spent the first year in plastic tunnels, and were then transferred to an open field for their second (C25 and C50) and third (C110 and $\mathrm{C} 350)$ growing season. In summer of the second year, C25 were again transferred into tunnels for two weeks in order to receive a short-day treatment with a photoperiod of $8 \mathrm{~h}$. This additional treatment was applied to $\mathrm{C} 25$ according to the criteria required by the Ministère des Ressources Naturelles (MRN 2013) for enabling seedlings to withstand the summer environmental conditions. The plant material homogeneity was verified by measuring the morphological characteristics of 20 seedlings per size ran- domly sampled before the experiment (Tab. 1).

On 24 July 2007, the seedlings were transplanted in 10 raised beds $(240 \mathrm{~cm} \times 120 \mathrm{~cm}$ $\times 14 \mathrm{~cm}$ ) arranged in 5 rows (blocks) and filled with sand $(<1 \%$ in loam). Therefore, the spacing between the seedlings was $10 \times$ $12 \mathrm{~cm}$, which assured no interaction or competition between the developing roots of seedlings. The raised beds were located in a plastic tunnel equipped with a forced ventilation set at $25{ }^{\circ} \mathrm{C}$. Eighty seedlings were planted along 10 rows per raised bed, and each row received two seedlings per size according to a random pattern. A row of C50 was planted along the perimeter of the raised bed to minimize the edge effect. Each block involved two raised beds randomly representing the control and the treatment. The raised beds were fertilized twice with $10 \mathrm{~g}$ of NPK (20-20-20) during two weeks of acclimatization.

Overall, the experiment lasted 25 days. The seedlings were irrigated every two days to maintain a volumetric soil water content of between 6 and $8 \%$, which was evaluated daily in each container by using a TDR probe (model MP-917, ESI Environmental Sensors Inc., Victoria, BC, Canada). Treated seedlings were submitted to a water stress beginning on 6 August during which irrigation was withheld for 14 days. After that period, irrigation was restored at the same frequency as the control, with measurements being maintained for the successive 11 days. Maximum and minimum air temperature and relative humidity were measured daily using two digital hygrometer-thermometer recorders (Fisher Scientific, Pittsburgh, PA, USA) located close to the seedlings.

\section{Data collection}

Physiological measurements were taken during and after the treatment for a total of 9 sampling days and consisted of pre-dawn $\left(\Psi_{\mathrm{pd}}\right)$ and midday $\left(\Psi_{\mathrm{md}}\right)$ leaf water potential, stomatal conductance to water vapour $\left(g_{\mathrm{s}}\right)$ and net photosynthesis $\left(P_{\mathrm{n}}\right)$. On each sampling day, 80 seedlings were randomly selected for data collection, 40 during predawn and 40 during midday measurements.

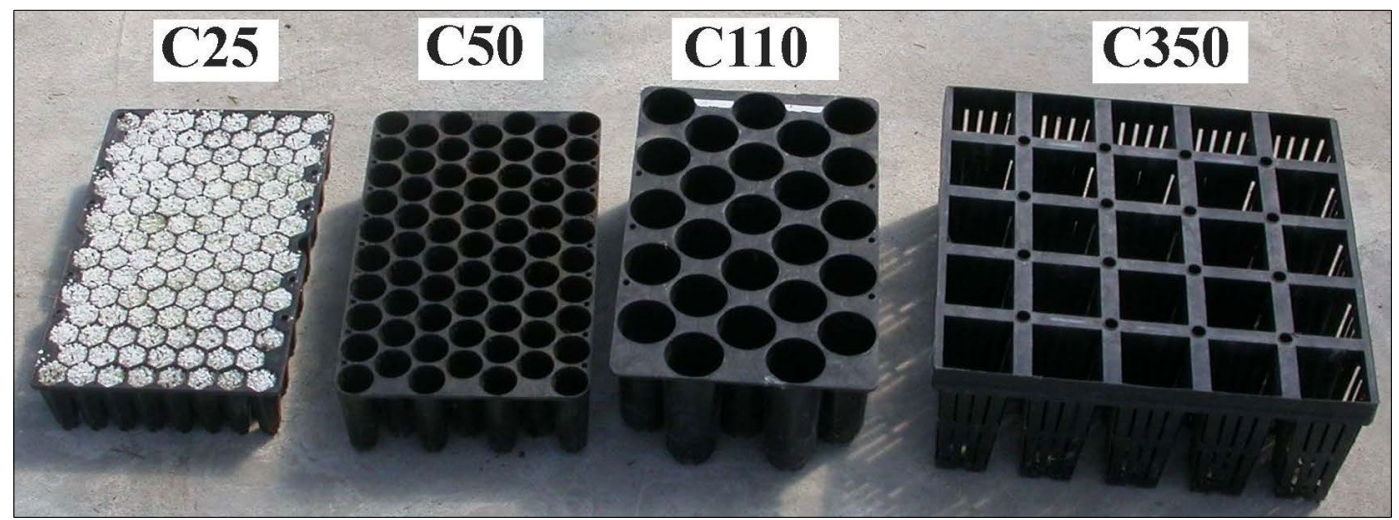

Fig. 1 - The four containers used to produce the seedlings for the experiment. 
$\Psi$ was measured with a pressure chamber (PMS Instruments, Corvalis, OR, USA). $A_{\mathrm{n}}$ and $g_{\mathrm{s}}$ were measured on the current-year needles of the apical arrow from 9:00 to 11:00 under saturating irradiance conditions $\left(1200 \mu \mathrm{mol} \mathrm{m}^{-2} \mathrm{~s}^{-1}\right)$ using a portable photosynthesis system LI-6400 (LI-COR, Inc. Lincoln, NB, USA) equipped with a conifers-adapted chamber of 0.251 . Measurements were expressed according to the needle dry mass, which was assessed after drying for $48 \mathrm{~h}$ at $65{ }^{\circ} \mathrm{C}$. After the measurements of gas exchange, $\Psi_{\mathrm{md}}$ was assessed on the same seedlings, the root system was collected, sealed in a plastic bag, and stored in the dark at $4{ }^{\circ} \mathrm{C}$. The roots were carefully cleaned in water, dried for $48 \mathrm{~h}$ at $65^{\circ} \mathrm{C}$ and weighed. Root density was determined on fresh samples with the method of volume displacement (Harrington et al. 1994).

\section{Statistical analyses}

Data were analyzed as split-split-plot with 5 replicate blocks, where each block contained control and treated seedlings. Overall, 720 seedlings were measured $(4$ sizes $\times 2$ water regimes $\times 5$ blocks $\times 9$ sampling days $\times 2$ periods of measurements). The variables related to physiological measurements were compared with analysis of variance (threeway ANOVA in a block-split-plit-plot design) and Restricted Maximum Likelihood Method REML procedure of the JMP ${ }^{\circledR}$ statistical software (version 10, SAS Institute Inc., Cary, NC, USA) by using seedling size as a categorical variable. The homogeneity of variance was graphically verified on residual plots of the linear models (Montgomery 1984). The SLICE procedure was used to analyze the interaction treatment $\times$ day, while the differences between seedling sizes were tested by orthogonal contrasts (Kirk 1982).

Analysis of covariance (ANCOVA) was used to assess the relationships between gas exchange and water potential, and to compare data of root biomass growth among seedling sizes. The models were applied on transformed data to respect the assumption of linearity. Goodness-of-fit of each model involved the significance of F-values, the proportion of variation accounted for $\left(\mathrm{R}^{2}\right)$ and the distribution of residuals.

\section{Results}

\section{Growth conditions}

During the overall period of monitoring, minimum and maximum temperatures were on average 13.6 and $30.6{ }^{\circ} \mathrm{C}$, respectively (Fig. 2). When treatment was carried out, from day 0 to 14 , the temperature was lower, 12.5 and $29.8^{\circ} \mathrm{C}$ for minimum and maximum, respectively. During the day, minimum relative humidity ranged between 17 and $64 \%$, and attained a maximum of 78 $97.5 \%$ at night. A rapid decrease in soil water content was observed two days after the suspension of irrigation in treated seedlings, which was followed by a gradual water loss reaching $1.4 \%$ of volumetric soil water content on day 7 (Fig. 2). After that date, soil water content remained stable until restoration of the irrigation. Two days of irrigations (day 14 and 16) were required for treated seedlings to attain soil water content values of $8.7 \%$, similar to those measured in the control.

\section{Water potential}

The control seedlings of all sizes main-
Fig. 2 - Environmental conditions and water content measured in black spruce seedlings submitted to water stress. Grey area represents the treatment period. Error bars indicate $95 \%$ confidence interval $(n=5)$.
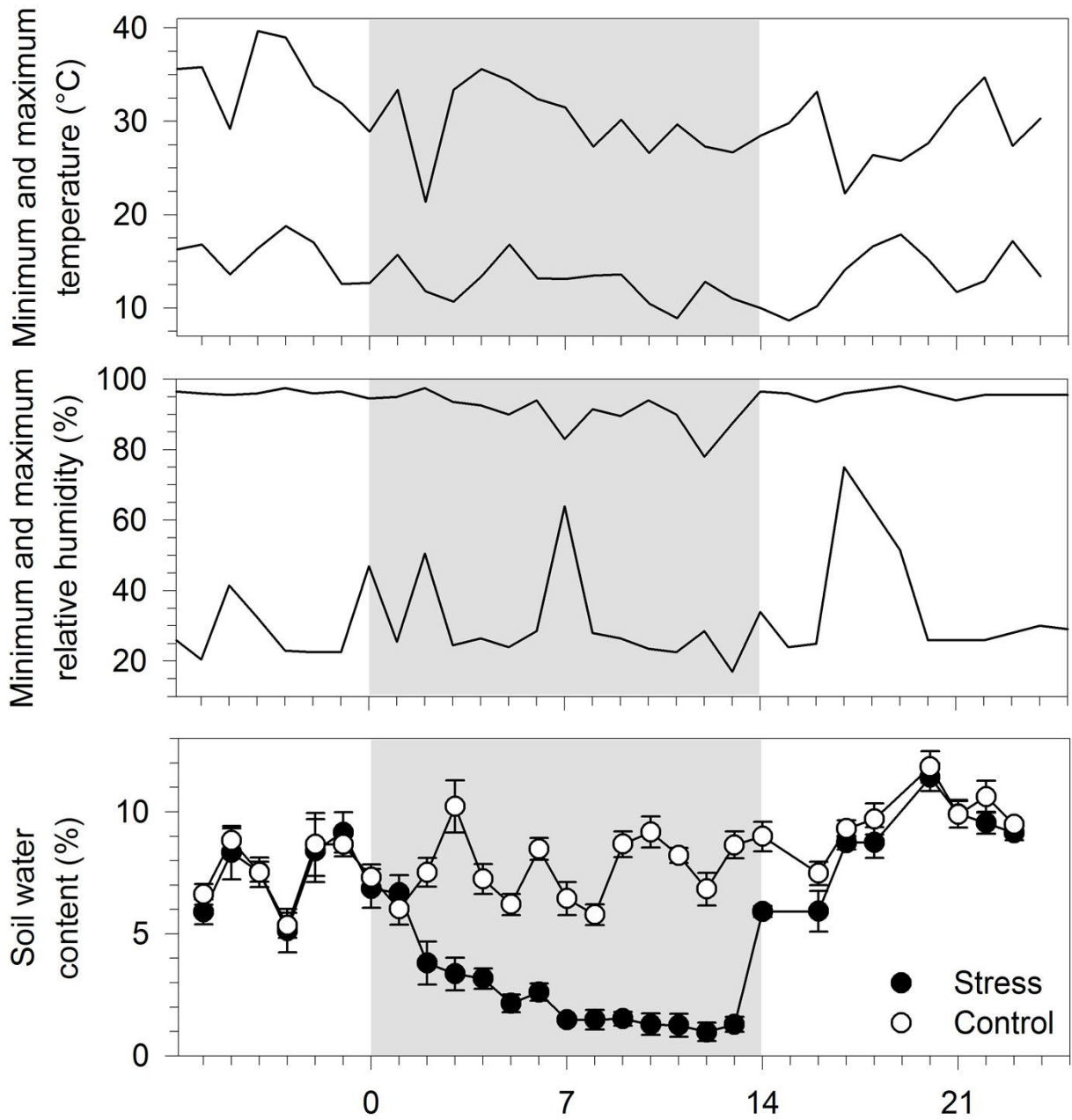

Days since the beginning of the treatment 

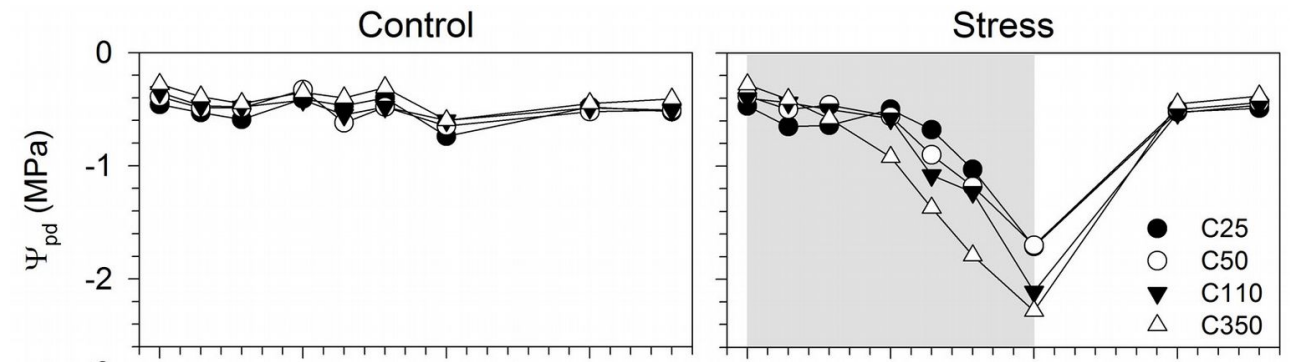

Fig. 3 - Physiological responses of black spruce seedlings of different sizes submitted to a water stress treatment. $\left(\Psi_{\mathrm{pd}}\right)$ : predawn leaf water potential; $\left(\Psi_{\mathrm{md}}\right)$ : midday leaf water potential; $\left(P_{\mathrm{n}}\right)$ : net photosynthesis; $\left(g_{\mathrm{s}}\right)$ : stomatal conductance to water vapour. C25, C50, C110 and C350 represent the different seedling sizes according to the cavity volume of the
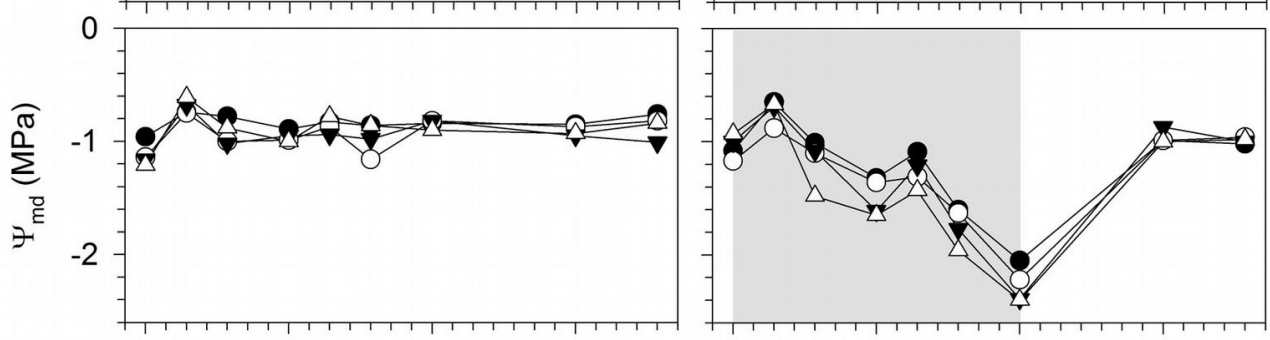
containers in which they were grown. Grey area represents the treatment period.
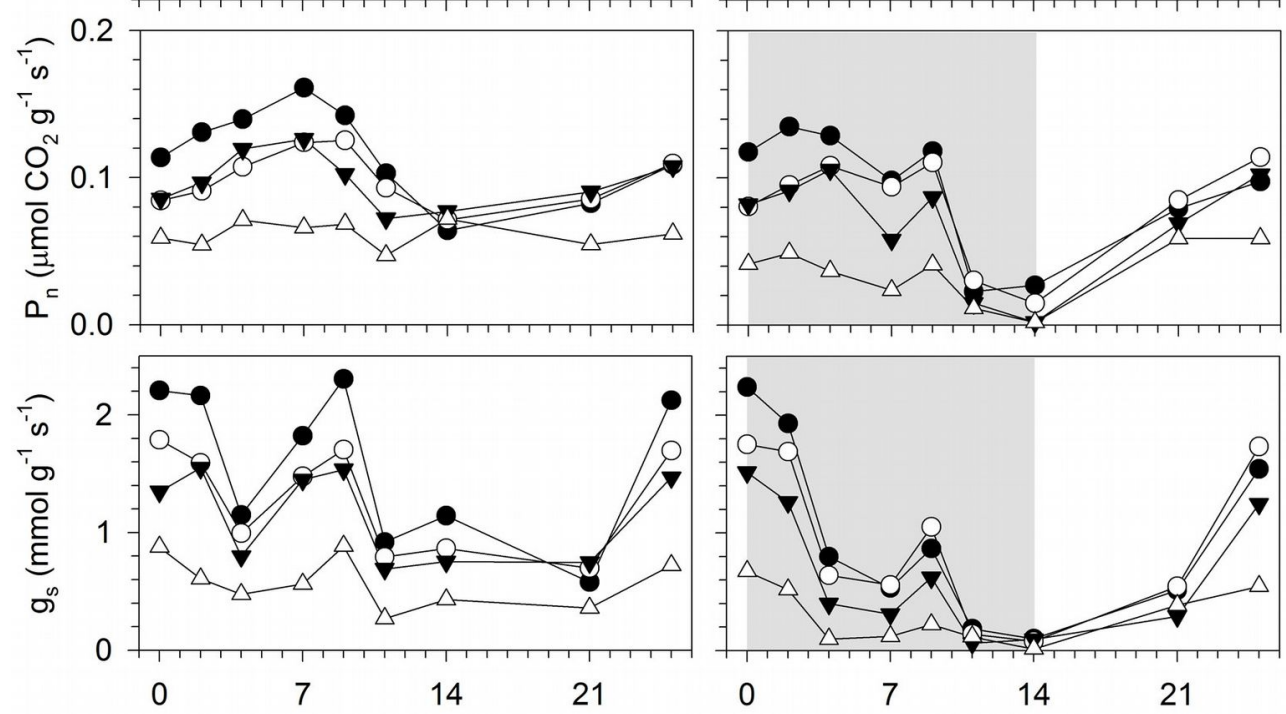

Days since the beginning of the treatment

Tab. 2 - ANOVA comparisons performed on the physiological measurements collected from black spruce seedlings of different sizes (S) submitted to a water stress treatment $(\mathrm{T}) .\left(\Psi_{\mathrm{pd}}\right)$ : predawn leaf water potential; $\left(\Psi_{\mathrm{md}}\right)$ : midday leaf water potential; $\left(P_{\mathrm{n}}\right)$ : net photosynthesis; $\left(g_{\mathrm{s}}\right)$ : stomatal conductance to water vapour. $\left(\mathrm{D}_{0}-\mathrm{D}_{25}\right)$ : days since the beginning of the treatment; (ns): not significant.

\begin{tabular}{|c|c|c|c|c|c|c|c|c|c|c|}
\hline \multirow{2}{*}{$\begin{array}{l}\text { Source of } \\
\text { variation }\end{array}$} & \multirow{2}{*}{ ndf } & \multirow{2}{*}{ ddf } & \multicolumn{2}{|c|}{$\Psi_{\mathrm{pd}}$} & \multicolumn{2}{|c|}{$\Psi_{\text {md }}$} & \multicolumn{2}{|c|}{$P_{\mathrm{n}}$} & \multicolumn{2}{|c|}{$g_{\mathrm{s}}$} \\
\hline & & & F-ratio & $\mathbf{p}$ & F-ratio & $\mathbf{p}$ & F-ratio & $\mathbf{p}$ & F-ratio & p \\
\hline Treatment (T) & 1 & 4 & 8.36 & $<0.05$ & 23.28 & $<0.01$ & 14.61 & $<0.05$ & 50.53 & $<0.01$ \\
\hline Day (D) & 8 & 64 & 17.25 & $<0.0001$ & 23.14 & $<0.0001$ & 28.05 & $<0.0001$ & 64.99 & $<0.0001$ \\
\hline $\mathrm{T} \times \mathrm{D}$ & 8 & 64 & 11.54 & $<0.0001$ & 20.31 & $<0.0001$ & 8.96 & $<0.0001$ & 9.67 & $<0.0001$ \\
\hline Between $\mathrm{T}$ at $\mathrm{D}_{0}$ & 1 & 64 & 0.01 & ns & 0.32 & ns & 0.26 & ns & 0.01 & ns \\
\hline Between $\mathrm{T}$ at $\mathrm{D}_{2}$ & 1 & 64 & 0.03 & ns & 0.05 & ns & 0.00 & ns & 1.07 & ns \\
\hline Between $\mathrm{T}$ at $\mathrm{D}_{4}$ & 1 & 64 & 0.06 & ns & 3.77 & ns & 2.08 & ns & 9.03 & $<0.01$ \\
\hline Between $\mathrm{T}$ at $\mathrm{D}_{7}$ & 1 & 64 & 2.24 & ns & 17.11 & $<0.001$ & 25.26 & $<0.0001$ & 58.93 & $<0.0001$ \\
\hline Between $\mathrm{T}$ at $\mathrm{D}_{9}$ & 1 & 64 & 8.05 & $<0.05$ & 10.09 & $<0.01$ & 4.02 & ns & 54.46 & $<0.0001$ \\
\hline Between $\mathrm{T}$ at $\mathrm{D}_{11}$ & 1 & 64 & 25.78 & $<0.0001$ & 36.94 & $<0.0001$ & 33.92 & $<0.0001$ & 19.20 & $<0.0001$ \\
\hline Between $\mathrm{T}$ at $\mathrm{D}_{14}$ & 1 & 64 & 55.21 & $<0.0001$ & 124.02 & $<0.0001$ & 34.85 & $<0.0001$ & 34.46 & $<0.0001$ \\
\hline Between $\mathrm{T}$ at $\mathrm{D}_{21}$ & 1 & 64 & 0.01 & ns & 0.24 & ns & 0.26 & $\mathrm{~ns}$ & 1.70 & ns \\
\hline Between $\mathrm{T}$ at $\mathrm{D}_{25}$ & 1 & 64 & 0.07 & ns & 1.08 & ns & 0.14 & ns & 3.65 & $\mathrm{~ns}$ \\
\hline Size $(\mathrm{S})$ & 3 & 215 & 1.80 & ns & 8.29 & $<0.0001$ & 148.06 & $<0.0001$ & 198.94 & $<0.0001$ \\
\hline $\mathrm{T} \times \mathrm{S}$ & 3 & 215 & 14.92 & $<0.0001$ & 3.66 & $<0.05$ & 1.63 & ns & 8.93 & $<0.0001$ \\
\hline $\mathrm{S} \times \mathrm{D}$ & 24 & 215 & 3.02 & $<0.0001$ & 1.14 & ns & 5.26 & $<0.0001$ & 7.20 & $<0.0001$ \\
\hline $\mathrm{T} \times \mathrm{S} \times \mathrm{D}$ & 24 & 215 & 2.79 & $<0.0001$ & 2.20 & $<0.01$ & 1.17 & $\mathrm{~ns}$ & 1.86 & $<0.0001$ \\
\hline
\end{tabular}


tained a similar and constant water potential during the experiment, with average $\Psi_{\text {pd }}$ and $\Psi_{\text {md }}$ of -0.47 and $-0.90 \mathrm{MPa}$, respectively (Fig. 3). The treatment modified both $\Psi_{\mathrm{pd}}$ and $\Psi_{\mathrm{md}}$ in seedlings of all sizes, with differences being statistically significant from day 7 for $\Psi_{\mathrm{md}}$ and 9 for $\Psi_{\mathrm{pd}}$ (Tab. 2). The differences between control and treated seedlings remained significant until day 14 . At the end of the treatment period, $\Psi_{\mathrm{pd}}$ and $\Psi_{\mathrm{md}}$ attained values of -2.2 and $-2.39 \mathrm{MPa}$, respectively. The significant interactions between size and treatment $(\mathrm{T} \times \mathrm{S}$ and $\mathrm{T} \times \mathrm{S} \times \mathrm{D}$ in $\mathrm{Tab} .2)$ indicated that the responses of water potential to stress was related to seedling size. Contrasts revealed that smaller seedlings $(\mathrm{C} 25$ and C50) had different $\Psi_{\mathrm{pd}}$ and $\Psi_{\text {md }}$ than bigger seedlings (C110 et $\mathrm{C} 350$ - Tab. 3). The differences between $\mathrm{C} 25$ and $\mathrm{C} 50$ and between C110 and C350 were occasionally significant. Differences in $\Psi_{\text {pd }}$ among seedlings sizes were larger than the differences in $\Psi_{\text {md }}$ (Fig. 3). No difference in water potential between control and treated seedlings was detected on days 21 and 25 , after restoration of the irrigation (Fig. 3 and Tab. 2). No seedlings was observed to die during or after the treatment.

\section{Gas exchange}

$P_{\mathrm{n}}$ and $g_{\mathrm{s}}$ of control seedlings were generally higher in $\mathrm{C} 25$, while $\mathrm{C} 350$ showed markedly lower but more stable values during the monitoring period (Fig. 3). The treatment significantly affected gas exchange (Tab. 2). $P_{\mathrm{n}}$ differed between control and
Tab. 3 - P-values of the orthogonal contrasts calculated for the days with significant effect of the treatment according to the ANOVA shown in Tab. 2. C25, C50, C110 and C350 represent the different seedling sizes according to the cavity volume of the containers in which they were grown. (ns): not significant.

\begin{tabular}{lcllll}
\hline Contrasts & Day & $\boldsymbol{\Psi}_{\text {pd }}$ & $\boldsymbol{\Psi}_{\text {md }}$ & $\boldsymbol{P}_{\mathbf{n}}$ & $\boldsymbol{g}_{\text {s }}$ \\
\hline (C25, C50) vs. & 4 & $\mathrm{~ns}$ & $<0.01$ & $<0.0001$ & $<0.0001$ \\
(C110, C350) & 7 & $<0.01$ & $<0.001$ & $<0.0001$ & $<0.01$ \\
& 9 & $<0.0001$ & $\mathrm{~ns}$ & $<0.0001$ & $<0.0001$ \\
& 11 & $<0.0001$ & $<0.01$ & $\mathrm{~ns}$ & $\mathrm{~ns}$ \\
& 14 & $<0.0001$ & $<0.01$ & $<0.05$ & $\mathrm{~ns}$ \\
\hline C25 vs. C50 & 4 & $\mathrm{~ns}$ & $\mathrm{~ns}$ & $\mathrm{~ns}$ & $\mathrm{~ns}$ \\
& 7 & $\mathrm{~ns}$ & $\mathrm{~ns}$ & $\mathrm{~ns}$ & $\mathrm{~ns}$ \\
& 9 & $<0.05$ & $\mathrm{~ns}$ & $\mathrm{~ns}$ & $\mathrm{~ns}$ \\
& 11 & $\mathrm{~ns}$ & $\mathrm{~ns}$ & $\mathrm{~ns}$ & $\mathrm{~ns}$ \\
& 14 & $\mathrm{~ns}$ & $\mathrm{~ns}$ & $\mathrm{~ns}$ & $\mathrm{~ns}$ \\
\hline C110 vs. C350 & 4 & $\mathrm{~ns}$ & $<0.001$ & $<0.0001$ & $\mathrm{~ns}$ \\
& 7 & $<0.01$ & $\mathrm{~ns}$ & $<0.01$ & $\mathrm{~ns}$ \\
& 9 & $<0.01$ & $\mathrm{~ns}$ & $<0.01$ & $<0.05$ \\
& 11 & $<0.0001$ & $\mathrm{~ns}$ & $\mathrm{~ns}$ & $\mathrm{~ns}$ \\
& 14 & $\mathrm{~ns}$ & $\mathrm{~ns}$ & $\mathrm{~ns}$ & $\mathrm{~ns}$ \\
\hline
\end{tabular}

Tab. 4 - Results of the ANCOVA models performed between $P_{\mathrm{n}}$ and $g_{\mathrm{s}}$ and $\Psi_{\mathrm{pd}}$ measured on black spruce seedlings of different sizes. The analysis was performed on transformed data to respect the assumption of linearity. (ns): not significant.

\begin{tabular}{llrrrrrc}
\hline \multirow{2}{*}{$\begin{array}{l}\text { Depen- } \\
\text { dent } \\
\text { variable }\end{array}$} & $\begin{array}{l}\text { Source of } \\
\text { variation }\end{array}$ & \multicolumn{3}{c}{ Regressors } & \multicolumn{3}{c}{ Model } \\
\cline { 2 - 7 } & $\begin{array}{c}\text { Type III } \\
\text { SS }\end{array}$ & F-value & $\boldsymbol{P}$ & F-value & $\boldsymbol{P}$ & \multirow{2}{*}{$\mathbf{R}^{\mathbf{2}}$} \\
\hline$P_{\mathrm{n}}$ & $\Psi_{\mathrm{pd}}$ & 0.034 & 81.11 & $<0.0001$ & 21.73 & $<0.0001$ & 0.70 \\
& seedling size & 0.013 & 10.42 & $<0.0001$ & & & \\
& $\Psi_{\mathrm{pd}} \times$ seedling size & 0.005 & 3.91 & $<0.05$ & & & \\
\hline$g_{\mathrm{s}}$ & $\Psi_{\mathrm{pd}}$ & 6.887 & 112.94 & $<0.0001$ & 23.57 & $<0.0001$ & 0.72 \\
& seedling size & 0.629 & 3.44 & $<0.05$ & & & \\
& $\Psi_{\mathrm{pd}} \times$ seedling size & 0.134 & 0.74 & $\mathrm{~ns}$ & & & \\
\hline
\end{tabular}

Fig. 4 - Relationships between $P_{\mathrm{n}}$ and $g_{\mathrm{s}}$ and $\Psi_{\mathrm{pd}}$ measured in black spruce seedlings of different sizes. The analysis was performed on transformed data to respect the assumption of linearity. $\left(\Psi_{\mathrm{pd}}\right)$ : predawn leaf water potential; $\left(P_{\mathrm{n}}\right)$ : net photosynthesis; $\left(g_{\mathrm{s}}\right)$ : stomatal conductance to water vapour. C25, C50,

$\mathrm{C} 110$ and $\mathrm{C} 350$ represent the different seedling sizes according to the cavity volume of the containers in which they were grown
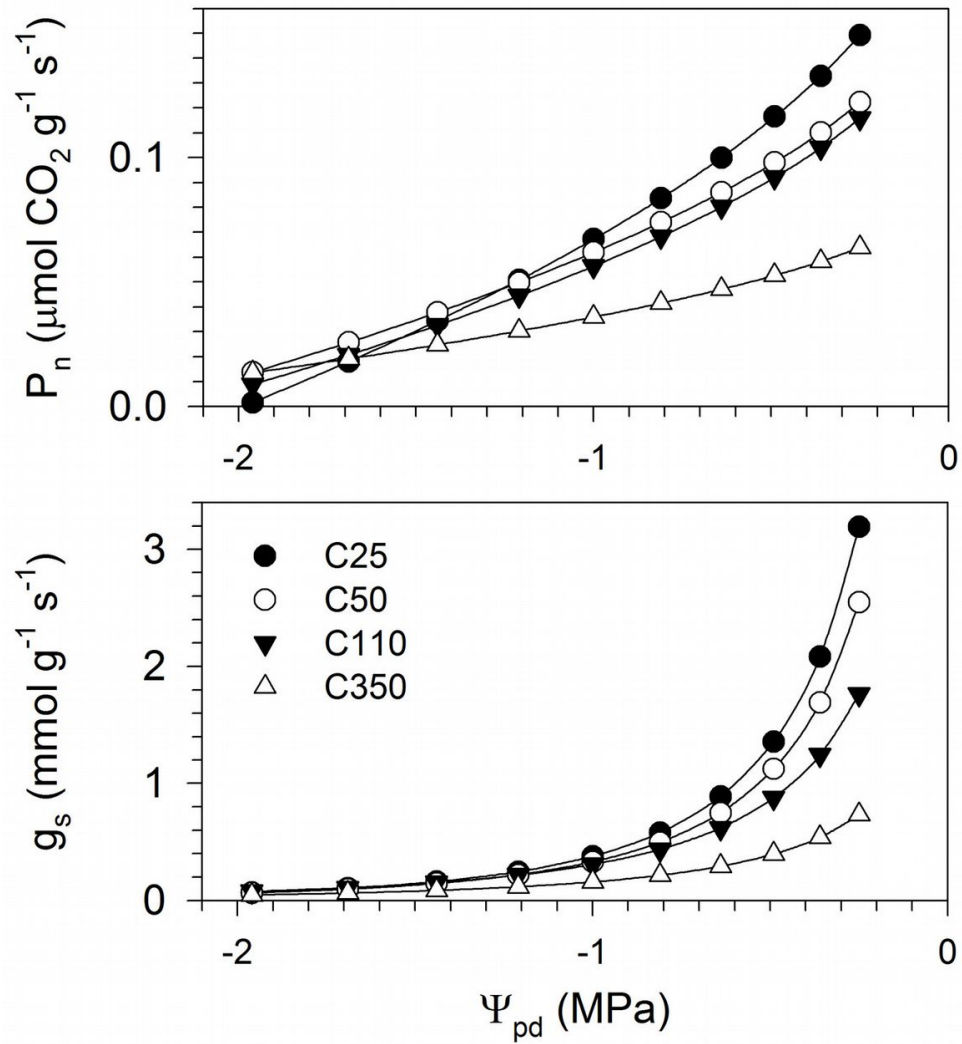


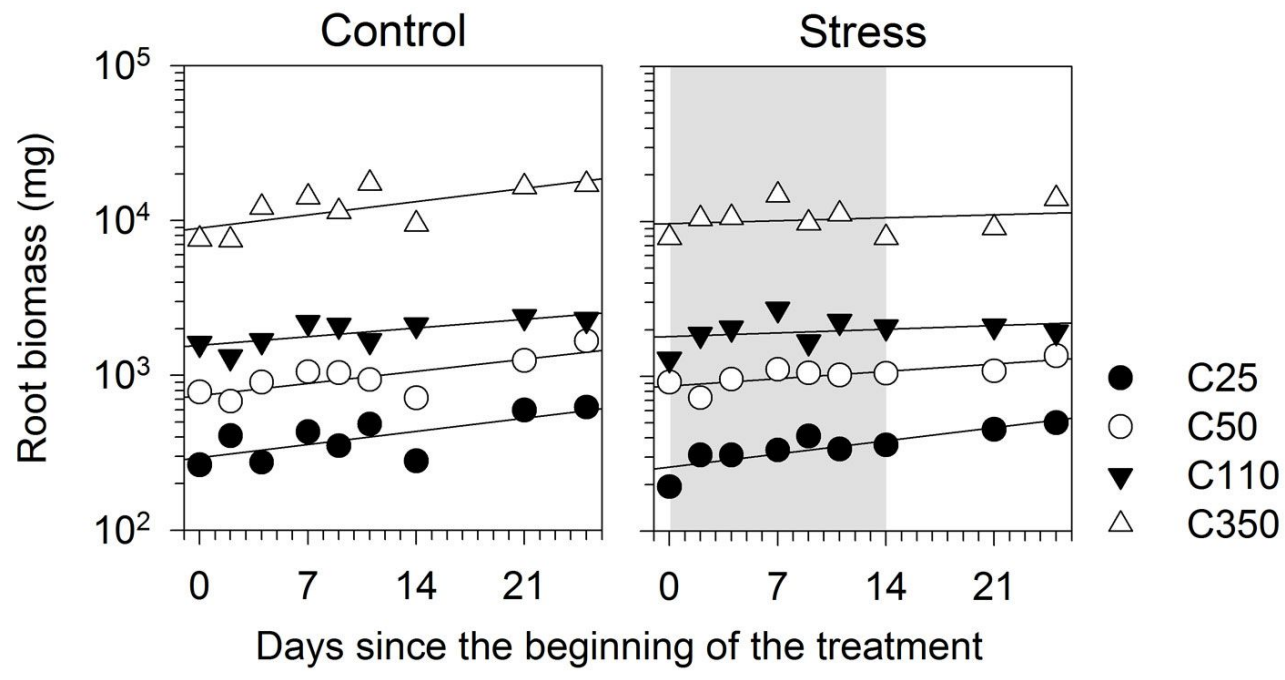

Fig. 5 - Root biomass of black spruce seedlings of different sizes submitted to a water stress treatment. Vertical axis is scaled at common logarithm. Grey area represents the treatment period.

treated seedlings on days 7,11 and 14, with the timings of response to water stress being related to the seedling size (significant interaction $\mathrm{S} \times \mathrm{D}$ in Tab. 2). On day 9, the smaller seedlings (C25 and C50) still showed higher $P_{\mathrm{n}}$ than bigger seedlings $(\mathrm{C} 110$ and C350). Similarly, C350 had the lowest $P_{\text {n }}$ until day 9 (Tab. 3). Eleven days after the suspension of irrigation, seedlings of all sizes attained similar $P_{\mathrm{n}}$ values (on average $0.02 \mu \mathrm{mol} \mathrm{CO}_{2} \mathrm{~g}^{-1} \mathrm{~s}^{-1}$ ), but markedly lower than those measured on the control $(0.08$ $\left.\mu \mathrm{mol} \mathrm{CO} \mathrm{g}^{-1} \mathrm{~s}^{-1}\right)$. At the end of water stress, on day $14, P_{\mathrm{n}}$ was statistically higher on smaller (C25 and C50) than on bigger seedlings (C110 and C350) (Tab. 3).

The effect of treatment on gas exchange was evident particularly for $g_{s}$, with differences between control and treated seedlings appearing 4 days after the suspension of irrigation (Fig. 3 and Tab. 2). On day 14, $g_{\text {s }}$ was on average 0.79 and $0.07 \mathrm{mmol} \mathrm{g}^{-1} \mathrm{~s}^{-1}$ in control and treated seedlings, respectively. Smaller seedlings (C25 and C50) maintained higher $g_{\mathrm{s}}$ than bigger seedlings $(\mathrm{C} 110$ and C350) on days 4-9. In general, C350 exhibited the lowest values of $g_{\mathrm{s}}$ in both control and treated seedlings (Tab. 3). The response in $g_{\mathrm{s}}$ of seedlings to the treatment was related to their size, as confirmed by the significant interaction $\mathrm{T} \times \mathrm{S}$ (Tab. 2).

The relationships between $P_{\mathrm{n}}$ and $g_{\mathrm{s}}$ and $\Psi_{\mathrm{pd}}$ were correctly represented by the AN-

COVA models, as revealed by the significant F-values and the high $\mathrm{R}^{2}$, which ranged between 0.70 and 0.72 (Tab. 4). The residuals were homogeneously distributed around zero, and showed no pattern, except a slight heteroscedasticity for $P_{\mathrm{n}}$. The general trend, which is represented in Fig. 4 by applying the inverse transformations on the model predictions for clarity, revealed a slow growth of the curves at low $\Psi_{\mathrm{pd}}$, followed by higher growth rates, producing an exponential pattern, mainly in $g_{s}$. Gas exchanges were positively correlated with water potential according to a non-linear pattern, and were related to seedling size, as also confirmed by the ANCOVA models (Tab. 4). For all seedling sizes, lower $\Psi_{\mathrm{pd}}$ corresponded to decreases in $P_{\mathrm{n}}$ and $g_{\mathrm{s}}$ (Fig. 4). However, for the same $\Psi_{\mathrm{pd}}$, smaller seedlings exhibited higher $P_{\mathrm{n}}$ and $g_{\mathrm{s}}$. The interaction $\Psi_{\mathrm{pd}}$ $\times$ seedling size was significant for $P_{\mathrm{n}}$, which indicated that seedlings of different sizes produced different slopes of the curves.

\section{Root biomass}

At the beginning of the treatment, root biomass ranged between 194 to $7820 \mathrm{mg}$ (Fig. 5). During the experiment, the roots grew significantly, as detected by the significant effect of day (Tab. 5). Root biomass was clearly related to seedling size, with bigger seedlings exhibiting higher root weights. Although the regression of $\mathrm{C} 25$ had a steeper

Tab. 5 - ANCOVA comparisons performed on root biomass of black spruce seedlings of different sizes submitted to a water stress treatment. The analysis was performed on log-transformed data to respect the assumption of linearity. (ns): not significant.

\begin{tabular}{lrrrc}
\hline Source of variation & ndf & ddf & F-ratio & p \\
\hline Treatment (T) & 1 & 4 & 0.66 & $\mathrm{~ns}$ \\
Day (D) & 8 & 64 & 15.83 & $<0.0001$ \\
$\mathrm{D} \times \mathrm{T}$ & 8 & 64 & 1.80 & $\mathrm{~ns}$ \\
Size (S) & 3 & 215 & 1237.71 & $<0.0001$ \\
$\mathrm{~T} \times \mathrm{S}$ & 3 & 215 & 1.51 & $\mathrm{~ns}$ \\
$\mathrm{~S} \times \mathrm{D}$ & 24 & 215 & 1.20 & $\mathrm{~ns}$ \\
$\mathrm{~T} \times \mathrm{S} \times \mathrm{D}$ & 24 & 215 & 0.71 & $\mathrm{~ns}$ \\
\hline
\end{tabular}

slope in treated seedlings, the interaction $D$ $\times$ T was not statistically significant $(\mathrm{p}>0.05)$, which indicated that root growth rates were similar between seedling sizes. No effect of water stress was observed on the growth in root biomass (Tab. 5).

\section{Discussion}

This experiment investigated some physiological responses of seedlings of different sizes to a water stress produced under controlled environmental conditions. Before the resumption of irrigation on day 14 , treated seedlings attained $\Psi_{\mathrm{pd}}$ of between -1.71 and $-2.28 \mathrm{MPa}$, indicating a severe water stress for black spruce (Colombo et al. 2001, Balducci et al. 2013). In general, both during and after the treatment, water potential and gas exchanges in $\mathrm{C} 25$, the seedlings of smallest size, were similar or higher than those measured in bigger seedlings (C50, $\mathrm{C} 110$ and $\mathrm{C} 350$ ). These results could in part be related by the short-day treatment that C25 seedlings received before the experiment. Reductions in $\Psi_{\mathrm{pd}}$ corresponded to declines in $P_{\mathrm{n}}$ and $g_{\mathrm{s}}$ in all seedlings, but for the same $\Psi_{\mathrm{pd}}$, smaller seedlings exhibited higher values of gas exchanges. No effect of the water stress was observed on the biomass of roots, which, although different in terms of absolute value between small and big seedlings, increased at the same rate in all seedling sizes. As a result, the initial hypothesis that small seedlings are more sensitive to a water stress was definitely rejected.

The stomatal conductance to water vapor of needles showed a higher sensitivity to water potential, with a clear reduction observed at $\Psi_{\text {pd }}$ of approximately -1.0 MPa, 4 days after the suspension of the irrigation. These results are in agreement with previous studies and confirmed that $\Psi_{\mathrm{pd}}$ of $-1.0 \mathrm{MPa}$ are sufficient to produce responses in black spruce (Balducci et al. 2013, Way et al. 2013). By reducing stomatal conductance to prevent water loss, seedlings substantially reduce 
their ability to assimilate carbon (Way et al. 2013). However, photosynthesis remained unaffected, or only slightly affected, by the treatment until day 11 , when $\Psi_{\mathrm{pd}}$ ranged between -2 and $-1.5 \mathrm{MPa}$. The high values of $P_{\mathrm{n}}$ at $\Psi_{\mathrm{pd}}$ of $-1.0 \mathrm{MPa}$ may thus suggest that the reduction in efficiency of water translocation or the effects of hydraulic failure through cavitation in 2- and 3-year-old seedlings could occur only when $\Psi_{\mathrm{pd}}$ reaches -1.5 $\mathrm{MPa}$. One week after the resumption of irrigation, water potential and gas exchanges measured in treated individuals had attained values similar to the control. At this point seedlings of all sizes could be considered to have completely recovered their optimal water balance and growth.

\section{Growth conditions during the experiment}

The experiment produced two contrasting water conditions during the treatment period, with volumetric soil water content decreasing quickly after the suspension of irrigation and reaching $1.4 \%$ within one week This was related to the use of a sandy substrate that allowed a rapid water loss. Such characteristics only partially represent the conditions experienced by planted seedlings on typical post-cutting soils in black spruce stands, which are deep and rich in organic material (Paquin \& Doucet 1992). However, black spruce regenerates naturally from the aerial seed banks released by its semi-serotinous cones during the immediate postfire periods, within three years after fire, mainly on mineral soils with a thin or missing layer of burnt humus (Rossi et al. 2013). Microsites with concave profiles or mosses are colonized more frequently by the seedlings, demonstrating that moisture is crucial for survival of black spruce regeneration (Wirth et al. 2008). Moreover, the plastic tunnels used in this investigation were not equipped to maintain an ideal temperature and relative humidity for growth. Thus, during the day temperatures exceeding $30{ }^{\circ} \mathrm{C}$ were measured and relative humidity decreased to 20 $40 \%$. Such environmental conditions, if prolonged, may inhibit root growth or damage the plant tissues in species adapted to cold and relatively humid climates (Darlington et al. 1997, Larcher 2003). Overall, the environmental conditions tested in this experiment could be considered less favorable to seedling growth in terms of water availability than those commonly met in post-fire stands by natural regeneration or in post-cutting areas destined to artificial regeneration.

\section{Factors affecting drought tolerance}

C25 had the lowest root density compared to seedlings of the bigger sizes, indicating that in proportion, a higher volume of soil was available for the roots of smaller seedlings, which have lower needle biomass and consequently need less water for the evapotranspiration process (Helenius et al. $2002,2005)$. The lower shoot:root ratio of smaller seedlings could also explain their ability to sustain an appropriate water status of the tissues. Increasing shoot:root ratios indicate the occurrence of higher proportions of leaves in respect to roots, whose biomass could be insufficient or less adequate to satisfy the water requirements for maintaining gas exchanges and photosynthesis. According to Bernier et al. (1995) the previous statement concerns bare-root seedlings and should be taken with caution in the case of containerized seedlings, which should experience no limiting factor. However, the container itself may represent a physical factor constraining root growth, as also deduced by the higher root density observed in C350 with respect to $\mathrm{C} 25$. It is well known that water absorption efficiency and seedling survival are negatively affected at high root densities (Baldwin et al. 1972, South \& Mitchell 2006). Moreover, although the biomass of each compartment increased according to the seedling size, bigger seedlings invested more in producing needles than roots, thus modifying the proportion between roots and needles (compare the dry weight of needles and roots in Tab. 1).

The growth of new roots is a key factor for the successful establishment of seedlings after planting. The definitive establishment allows a sufficient rate of water and nutrient uptake to be sustained in the long term or during stressful events, which can occur early and frequently in boreal forests (Philipson 1988, Tan et al. 2008). Root growth can be affected by water stress that inhibits division and differentiation of the cells at the apical meristem of roots (Hsiao 1973). Root growth is also related to the availability of photosynthates for meristem development (Krabel 2000). Under similar environmental conditions and water potentials, the smaller seedlings demonstrated an ability to maintain higher rates of gas exchanges than the other seedlings. Delayed stomatal closures ensure the $\mathrm{CO}_{2}$ assimilation for completing the photosynthetic process even under unfavorable environmental conditions. Accordingly, the slope of the regression for $\mathrm{C} 25$ was steeper than those estimated for the other seedling sizes, suggesting higher growth rates in smaller seedlings. However, no statistical difference in root growth was observed during the treatment. Thus, it was concluded that root growth in smaller seedlings was comparable to that observed in the other seedling sizes.

\section{Size vs. age effect}

The slow growth of black spruce prevents sizes suitable for planting to be attained within short periods. As a result, in seedlings of this species the size is intrinsically depen- dent on age. Moreover, production of the experimental seedlings carefully respected the standard criteria adopted by the forest tree nurseries in Quebec to make the results representative and effective for practitioners. Thus, in this investigation, the factor age covariated with seedling size, as either 2- or 3year-old seedlings were used for small or big seedlings, respectively. This prevented identification of the main factor triggering the physiological performances of seedlings. Bigger seedlings have a less branched root system and lower proportions of unsuberized fine roots, and could be less efficient in water and nutrient uptake (Johansson et al. 2012). This different permeability of roots could also explain the higher concentration of several foliar nutrients observed in $\mathrm{C} 25$ compared to C50 (Tremblay et al. 2013). The higher metabolism and greater capacity for enhancing photosynthesis should allow smaller and younger plants to endure the stress (Boege 2005). Although there is evidence that the effect may be ascribed mainly to seedling size rather than age (Mencuccini et al. 2005), in this work the correlated factors size and age were not disentangled. As a result, the question whether the differences observed were connected to the physiological features related to seedling size or age remained unanswered.

\section{Other effects}

Before the experiment, C25, the smaller seedlings, were transferred to tunnels for two weeks to receive a short-day treatment. This was not provided for the seedlings of the other sizes. Such a treatment is contemplated by the protocol of forest tree nurseries of Quebec and currently used to induce growth cessation and bud set in seedlings, mainly for those planted in summer, which should be better enabled to withstand summer environmental conditions (Grossnickle 2000). Compared with seedlings grown under longday conditions, there is agreement that this treatment increases root growth and drought and frost tolerance of seedlings (Folk \& Grossnickle 1997, Grossnickle \& Folk 2003, Luoranen et al. 2007). The short-day treatment is expected to promote photosynthesis, reduce respiration, and increase the proportion of carbon allocated to roots (Hawkins et al. 1994). Thus, the performance observed in C25 during the investigation could be in part attributed to the short-day treatment received before the experiment.

Another factor possibly affecting the results was related to the characteristics of containers. As shown in Fig. 1, the largest container had side slits, which were missing in the other containers. There is a potential for the side slits to have altered the morphology or post-planting growth of the roots, in addition to the intended effect of container size. Although this factor could not be ex- 
cluded and should be taken into account, no marked effect was detected in the results.

\section{Conclusions}

Post-cutting regeneration is a critical period for successful and effective forest management, and is costly in the case of seeding or planting. The resistance to stress of seedlings during their first phases after planting is fundamental for avoiding a growth check and assuring fast establishment and long-term survival. There is increasing interest in seedlings of small sizes for artificial regeneration because they need less storage space and handling. However, the resistance of small seedlings to water deficit is questioned. In this work, the response to a severe water deficit produced by a suspension of irrigation for 14 days was assessed in black spruce seedlings of different sizes. Smaller seedlings exhibited similar or higher water potential and gas exchanges than bigger seedlings both during and after the treatment. The root growth of both small and big seedlings was not affected by the water stress. The initial hypothesis that small seedlings are more sensitive to a water stress was thus definitely rejected. The performances observed in smaller seedlings were attributed to higher ability of roots to sustain the evaporative needs of needles under water deficit and to maintain higher rates of carbon assimilation. However, the smaller seedlings were also necessarily younger, thus the question whether the differences observed were connected to their size or age remained unanswered.

The results of this experiment suggested that the performance in terms of tolerance to water stress and maintenance of root growth during a water deficit was similar in seedlings of small and big size, even under temperatures warmer than those generally occurring in typical boreal forests dominated by black spruce. Moreover, delayed stomata closures were observed to occur in smaller seedlings, which allowed higher rates of photosynthesis to be maintained than in bigger seedlings. Given the financial and logistic advantage of using smaller seedlings in artificial regeneration, their utilization should be seriously considered and tested in boreal stands experiencing occasional drought events or non-optimal soil moisture conditions.

\section{References}

Balducci L, Deslauriers A, Giovannelli A, Rossi S, Rathgeber CBK (2013). Effects of temperature and water deficit on cambial activity and woody ring features in Picea mariana saplings. Tree Physiology 33: 1006-1017. - doi: 10.1093/ treephys/tpt073

Baldwin JP, Tinker PB, Nye PH (1972). Uptake of solutes by multiple root systems from soil. Plant and Soil 36: 693-708. - doi: 10.1007/BF013
73517

Belien E, Rossi S, Morin H, Deslauriers A (2012). Xylogenesis in black spruce subjected to a rain exclusion in the field. Canadian Journal of Forest Research 42: 1306-1315. - doi: 10.1139/x2012095

Bernier PY, Lamhamedi MS, Simpson DG (1995). Shoot: root ratio is of limited use in evaluating the quality of container conifer stock. Tree Planters' Notes 46: 102-106. [online] URL: http://www.cfs.nrcan.gc.ca/publications/?id=337 15

Boege K (2005). Influence of plant ontogeny on compensation to leaf damage. American Journal of Botany 92: 1632-1640. - doi: 10.3732/ajb. 92.10.1632

Burdett AN (1990). Physiological processes in plantation establishment and the development of specifications for forest planting stock. Canadian Journal of Forest Research 20: 415-427. - doi: 10.1139/x90-059

Colombo J, Sampson PH, Templeton CWG, McDonaugh TC, Menes PA, DeYoe D, Grossnickle SC (2001). Assessment of nursery stock quality in Ontario. In: "Regenerating the Canadian forest, Principles and practice for Ontario" (Wagner RG, Colombo J eds). Fitzhenry and Whiteside Limited, Markham, ON, Canada, pp. 307-323. Danielsson M, Kannaste A, Lindstrom A, Hellqvist C, Stattin E, Langstrom B, Borg-Karlson AK (2008). Mini-seedlings of Picea abies are less attacked by Hylobius abietis than conventional ones: is plant chemistry the explanation? Scandinavian Journal of Forest Research 23: 299-306. - doi: 10.1080/02827580802203560

Darlington AB, Halinska A, Dat JF, Blake TJ (1997). Effects of increasing saturation vapour pressure deficit on growth and ABA levels in black spruce and jack pine. Trees 11: 223-228. doi: $10.1007 / \mathrm{s} 004680050079$

Folk RS, Grossnickle SC (1997). Determining field performance potential with the use of limiting environmental conditions. New Forests 13: 121-138. - doi: 10.1023/A:1006514805052

Grossnickle SC (2000). Ecophysiology of northern spruce species: the performance of planted seedlings. NRC Research Press, Ottawa, Canada, pp. 407. - [online] URL: http://www.nrcresearchpress.com/doi/abs/10.1139/9780660179599\#.V H8m9TGG_vI

Grossnickle SC, Folk RS (1993). Stock quality assessment: forecasting survival or performance on a reforestation site. Tree Planters' Notes 44: 113121. [online] URL: http://admin.rngr.net/publications/tpn/44-3/stock-quality-assessment-forecasting-survival-or-performance-on-a-reforestation-site

Grossnickle SC, Folk RS (2003). Spring versus summer spruce stocktypes of western Canada: nursery development and field performance. Western Journal of Applied Forestry 18: 267275. [online] URL: http://www.ingentaconnect.com/content/saf/wjaf/2003/00000018/00000004/ art00007

Harrington JT, Mexal JG, Fisher JT (1994). Volume displacement provides a quick and accurate way to quantify new root production. Tree Planters' Note 45: 121-124. [online] URL: http://morasc.nmsu.edu/docs/VolumeDisplacementProvidesaQuickandAccurateWaytoQuantifyNewRootProd.pdf

Hawkins CDB, Eng RYN, Krasowski MJ (1994). Short day nursery treatment promotes photosynthesis in interior spruce seedlings: summary of poster. In: "National proceedings, Forest and conversation nursery associations" (Landis TD, Dumroese RK eds). Rocky Mountain Forest and Range Experiment Station, USDA Forest Service, Fort Collins, CO, USA, pp. 3. [online] URL: http://www.rngr.net/publications/proceedings/1994/hawkins.pdf

Hébert F, Boucher J-F, Bernier PY, Lord D (2006). Growth response and water relations of 3-year-old planted black spruce and jack pine seedlings in site prepared lichen woodlands. Forest Ecology and Management 223: 226-236 doi: 10.1016/j.foreco.2005.11.005

Hébert F, Boucher J-F, Walsh D, Côté D, Lord D (2014). Black spruce growth and survival in boreal open woodlands 10 years following mechanical site preparation and planting. Forestry 87 : 277-286. - doi: 10.1093/forestry/cpt052

Helenius P, Luoranen J, Rikala R (2005). Effect of preplanting drought on survival, growth and xylem water potential of actively growing Picea abies container seedlings. Scandinavian Journal of Forest Research 20: 103-109. - doi: 10.1080/02827580510008239

Helenius P, Luoranen J, Rikala R, Leinonen K (2002). Effect of drought on growth and mortality of actively growing Norway spruce container seedlings planted in summer. Scandinavian Journal of Forest Research 17: 218-224. - doi: $10.1080 / 028275802753742882$

Hsiao TC (1973). Plant responses to water stress. Annual Review of Plant Physiology 24: 519-570. - doi: 10.1146/annurev.pp.24.060173.002511

Huang J-G, Tardif J, Bergeron Y, Denneler B, Berninger F, Girardin M (2010). Radial growth response of four dominant boreal tree species to climate along a latitudinal gradient in the eastern Canadian boreal forest. Global Change Biology 16: 711-731. - doi: 10.1111/j.1365-2486.2009. 01990.x

Jobidon R, Charette L, Bernier PY (1998). Initial size and competing vegetation effects on water stress and growth of Picea mariana (Mill. ) BSP seedlings planted in three different environments. Forest Ecology and Management 103: 293-305. - doi: 10.1016/S0378-1127(97)002284

Johansson K, Nilsson U, Allen HL (2007) Interactions between soil scarification and Norway spruce seedling types. New Forests 33 (1):13-27. - doi: 10.1007/s1 1056-006-9010-y

Johansson K, Langvall O, Bergh J (2012). Optimisation of environmental factors affecting initial growth of Norway spruce seedlings. Silva Fennica 46: 27-38. - doi: 10.14214/sf.64

Jutras S, Thiffault N, Munson AD (2007). Comparing large bareroot and container stock: water stress as influenced by peat and soil water avai- 
lability. Tree Planters' Notes 52: 15-18. [online] URL: http://www.rngr.net/publications/tpn/52-1/ Kirk RE (1982). Experimental design: procedures for the behavioral sciences. Brooks/Cole Publishing, Belmont, CA, USA, pp. 911.

Krabel D (2000). Influence of sucrose on cambial activity. In: "Cell and molecular biology of wood formation" (Savidge RA, Barnett JR, Napier R eds). BIOS Scientific Publishers Ltd., Oxford, UK, pp. 113-125.

Lamhamedi MS, Bernier PY, Hebert C, Jobidon R (1998). Physiological and growth responses of three sizes of containerized Picea mariana seedlings outplanted with and without vegetation control. Forest Ecology and Management 110: 13-23. - doi: 10.1016/S0378-1127(98)00267-9

Larcher W (2003). Physiological plant ecology: ecophysiology and stress physiology of functional groups. Springer-Verlag, Berlin, Germany, pp. 513.

Lindström A, Hellqvist C, Stattin E (2005). Mini seedlings - a new forest regeneration system. In: Proceedings of the Symposium "The thin green line - A symposium on the state-of-the-art in reforestation" (Colombo J ed). Thunder Bay (ON, Canada) 26-28 July 2005. Ontario Forest Research Institute, Ontario Ministry of Natural Resources, Thunder Bay, ON, Canada, pp. 56-58.

Luoranen J, Helenius P, Huttunen L, Rikala R (2007). Short-day treatment enhances root egress of summer-planted Picea abies seedlings under dry conditions. Scandinavian Journal of Forest Research 22: 384-389. - doi: 10.1080/02827580 701551382

Mencuccini M, Martínez-Vilalta J, Vanderklein D, Hamid HA, Korakaki E, Lee S, Michiels B (2005). Size-mediated ageing reduces vigour in trees. Ecology Letters 8: 1183-1190. - doi: 10.11 11/j.1461-0248.2005.00819.x

Montgomery DC (1984). Design and analysis of experiments John Wiley, New York, USA, pp. 643.

MRN (2013). Guide terrain: inventaire de qualification des plants résineux cultivés en récipients [Field guide: qualification inventory of conifers grown in containers]. Ministère des Ressources naturelles, Direction générale des pépinières et des stations piscicoles, Division de la production des plants forestiers, Sainte-Foy, Québec, Canada, pp. 141. [in French]

Natural Resources Canada (2012). The state of Canada's forests. Annual report. Canadian Forest Service, Ottawa, Canada, pp. 52.

Nilsson U, Luoranen J, Kolstrom T, Orlander G, Puttonen P (2010). Reforestation with planting in northern Europe. Scandinavian Journal of Forest Research 25: 283-294. - doi: 10.1080/02827 581.2010.498384

Nishimura PH, Laroque CP (2011). Observed continentality in radial growth-climate relationships in a twelve site network in western Labrador, Canada. Dendrochronologia 29: 1723. - doi: 10.1016/j.dendro.2010.08.003

Paquin R, Doucet R (1992). Croissance en hauteur à long terme de la régénération préétablie dans des pessières noires boréales régénérées par marcottage, au Québec [Long-term height growth of advanced regeneration in boreal black spruce forests regenerated by layering in Quebec]. Canadian Journal of Forest Research 22: 613-621. - doi: 10.1139/x92-081

Philipson JJ (1988). Root growth in Sitka spruce and Douglas-fir transplants: dependence on the shoot and stored carbohydrates. Tree Physiology 4: 101-108. - doi: 10.1093/treephys/4.2.101

Rossi S, Morin H, Deslauriers A (2011). Multi- scale influence of snowmelt on xylogenesis of black spruce. Arctic, Antarctic, and Alpine Research 43: 457-464. - doi: 10.1657/1938-424643.3.457

Rossi S, Morin H, Gionest F, Laprise D (2013). Spatially explicit structure of natural stands dominated by black spruce. Silva Fennica 47 : 973. - doi: 10.14214/sf.973

South DB, Mitchell RG (2006). A root-bound index for evaluating planting stock quality of container-grown pines. Southern African Forestry Journal 207: 47-54. - doi: 10.2989/10295920609 505252

Tan W (2007). Impacts of nursery cultural treatments on stress tolerance in $1+0$ container white spruce (Picea glauca [Moench] Voss) seedlings for summer-planting. New Forests 33: 93-107. doi: $10.1007 /$ s1 1056-006-9016-5

Tan W, Blanton S, Bielech JP (2008). Summer planting performance of white spruce $1+0$ container seedlings affected by nursery short-day treatment. New Forests 35: 187-205. - doi: 10.1007/s11056-007-9071-6

Tremblay P, Boucher JF, Tremblay M, Lord D (2013). Afforestation of boreal open woodlands: early performance and ecophysiology of planted black spruce seedlings. Forests 4: 433-454. - doi: 10.3390/f4020433

Way DA, Crawley C, Sage RF (2013). A hot and dry future: warming effects on boreal tree drought tolerance. Tree Physiology 33: 10031005. - doi: 10.1093/treephys/tpt092

Wirth C, Lichstein JW, Dushoff J, Chen A, Chapin III FS (2008). White spruce meets black spruce: dispersal, postfire establishment, and growth in a warming climate. Ecological Monographs 78: 489-505. - doi: 10.1890/07-0074.1 